\title{
A Sensitivity Analysis of Impacts of Conservation Practices on Water Quality in L'Anguille River Watershed, Arkansas
}

\author{
Gurdeep Singh ${ }^{1}$, Dharmendra Saraswat ${ }^{2, *}$ and Andrew Sharpley ${ }^{3}$ \\ 1 Research Data Engineer, The Climate Corporation, St. Louis, MO 63141, USA; gurdeep.singh@climate.com \\ 2 Department of Agricultural \& Biological Engineering, Purdue University, West Lafayette, IN 47907, USA \\ 3 Department of Crop, Soil and Environmental Sciences, University of Arkansas, Fayetteville, AR 72701, USA; \\ sharpley@uark.edu \\ * Correspondence: saraswat@purdue.edu; Tel.: +1-765-494-5013
}

Received: 8 March 2018; Accepted: 5 April 2018; Published: 8 April 2018

\begin{abstract}
Assessing the performance of appropriate agricultural conservation practices (CPs) frequently relies on the use of simulation models as a cost-effective tool instead of depending solely on the monitoring of water quality at individual field and watershed levels. This study evaluates the predicted impacts of several CPs on nutrient and sediment loss at the hydrological response unit scale in the L'Anguille River Watershed, which is a watershed identified as a "focus watershed" under the Mississippi River Basin healthy watershed Initiative (MRBI) program. The Soil and Water Assessment Tool model was calibrated and validated between 1998-2005 and 2006-2012, respectively for flow, sediment, total phosphorus, and nitrate nitrogen. Out of the seven MRBI CPs modeled in this study, the highest reduction in sediment $(80 \%)$ and nutrient $(58 \%$ for total phosphorus and $16 \%$ for total nitrogen) was predicted for the critical area planting practice, followed by filter strip, irrigation land leveling, grade stabilization structure, irrigation pipeline, nutrient management, and irrigation water management. Some of the predicted impacts conflicted with expected $\mathrm{CP}$ performance. The study underscores the importance of the proper formulation of $\mathrm{CP}$ algorithms in using simulation models for predicting impacts on water quality.
\end{abstract}

Keywords: conservation practice; environmental modeling; SWAT

\section{Introduction}

Agricultural sources have been reported to increase sediment losses [1] and cause hypoxia problems in the Gulf of Mexico by contributing more than $70 \%$ of the delivered nitrogen $(\mathrm{N})$ and phosphorus (P) in the Mississippi River Basin [2]. Reports in the mid-2000s implied that commodity payments ( $\$ 52.2$ billion), which were appreciably higher than conservation subsidies ( $\$ 8.5$ billion) for farms in the MRB (1995 to 2002), contributed to greater N and P loads discharging into the Gulf, and thereby an increase in the hypoxic zone (Environmental Working Group, 2006-http:/ /www.ewg.org/ reports/deadzone).

The generation and delivery of agricultural sediments such as $\mathrm{N}$ and $\mathrm{P}$ can be minimized by the implementation of various conservation practices (CPs) [3,4]. It is important to note that farmers' motivations are largely responsible for the implementation of CPs on farms [5]. In order to support the adoption and tracking of conservation measures, the United States Department of Agriculture (USDA) Natural Resources Conservation Service (NRCS) launched the Mississippi River Basin healthy watershed Initiative (MRBI) in 2009 by providing $\$ 320$ million over five years [3,6]. The MRBI initiative's objective is to help producers in designated MRBI watersheds obtain cost-share funding to implement CPs, mainly to control sediment and nutrients [7]. 
The MRBI concentrated its activities on 41 "focus" watersheds in 13 states: Arkansas, Kentucky, Illinois, Indiana, Iowa, Louisiana, Minnesota, Mississippi, Missouri, Ohio, South Dakota, Tennessee, and Wisconsin [7]. In Arkansas, the focus watersheds (8-digit Hydrologic Unit Code, or HUC) are Bayou Macon (08050002), Boeuf (08050001), Cache (08020302), L'Anguille (08020205), Little River Ditches (08020204), Lower St. Francis (08020203), and Point Remove-Lake Conway (11110203) [8]. One objective of the MRBI is to quantify the effectiveness of adopted CPs at reducing sediment and nutrient losses in each of the focus watersheds, via a three-tiered monitoring strategy [6]. This involves spatially explicit monitoring at edge-of-field and 12 and 8-digit HUC scales. A comprehensive description of the HUC is given in [9]. The reliable quantification of nutrient and sediment reductions from land management practices at the HUC scales is difficult $[10,11]$. Monitoring is costly and labor intensive. Nonpoint source models provide a practical alternative to estimate outcomes [12].

The Soil and Water Assessment Tool (SWAT) model has widespread application in assessing various environmental scenarios. It is freely available, has been actively supported and developed, and has the flexibility to simulate various CPs $[13,14]$. The SWAT model divides a watershed into sub-watersheds, and sub-watersheds into hydrological response units (HRUs). The HRUs are delineated by the overlay of land use, soil, and slope coverages. The threshold percentages for land use, soil, and slope are used to refine out very small areas to simplify the model structure and limit the number of HRUs [15]. Any land use, soil, or soil that occupies a percentage of the sub-watershed area that is less than the threshold level percentage is eliminated and not considered in the HRU distributions. For example, if a $25 \%$ threshold level is defined for soil, only the soils that occupy more than $25 \%$ of the sub-watershed area are considered in the HRU distributions. A 0\%, or no-threshold level that is defined for the land use, soil, and slope will preserve all of the spatial details in the watershed, as none of the land uses, soils, or slopes are eliminated from the HRU distributions. Commonly-used thresholds range from 5\% to 15\% [16]. The thresholds for refining HRUs result in a loss of information, but this may be justified by a reduction in the computational cost [17]. It has been recommended that smaller thresholds (preferably $0 \%$, or no thresholds for land use, soil, and slope) should be used for delineating HRUs if the focus of study is (1) water quality assessment or (2) the incorporation of location information for CPs [16].

The overall objective of this study was to assess the predicted impacts of selected MRBI-recommended CPs on water quality (measured via a percentage reduction in the sediment and nutrient losses) of the L'Anguille River Watershed (LRW) using SWAT with no thresholds for land use, soil, and slope to create HRUs. Specific objectives were:

1. Parameterizing SWAT for LRW by enhancing the model setup procedure,

2. Calibrating and validating the SWAT model,

3. Incorporating MRBI-recommended CPs in the SWAT model, and

4. Assessing the impacts of selected MRBI CPs on water quality of LRW.

\section{Materials and Methods}

\subsection{Study Area}

Land use in the LRW is predominantly agricultural, with $69.2 \%, 18.9 \%, 5.1 \%, 3.5 \%, 1.9 \%$, and $1.4 \%$ in crop, forest, pasture, urban, barren, and water, respectively. It is located in the Mississippi Delta ecoregion of east central Arkansas (Figure 1). The LRW drains an area of 2474 square kilometer in the LRW, and land covers in the LRW are corn, cotton, rice, soybean, and specialty crops (mixed land uses: tomatoes, watermelon, etc.) [18]. The Arkansas Natural Resources Commission reported LRW as a priority watershed for nutrients for the 2011-2016 Nonpoint source Pollution Management Plan [19]. 


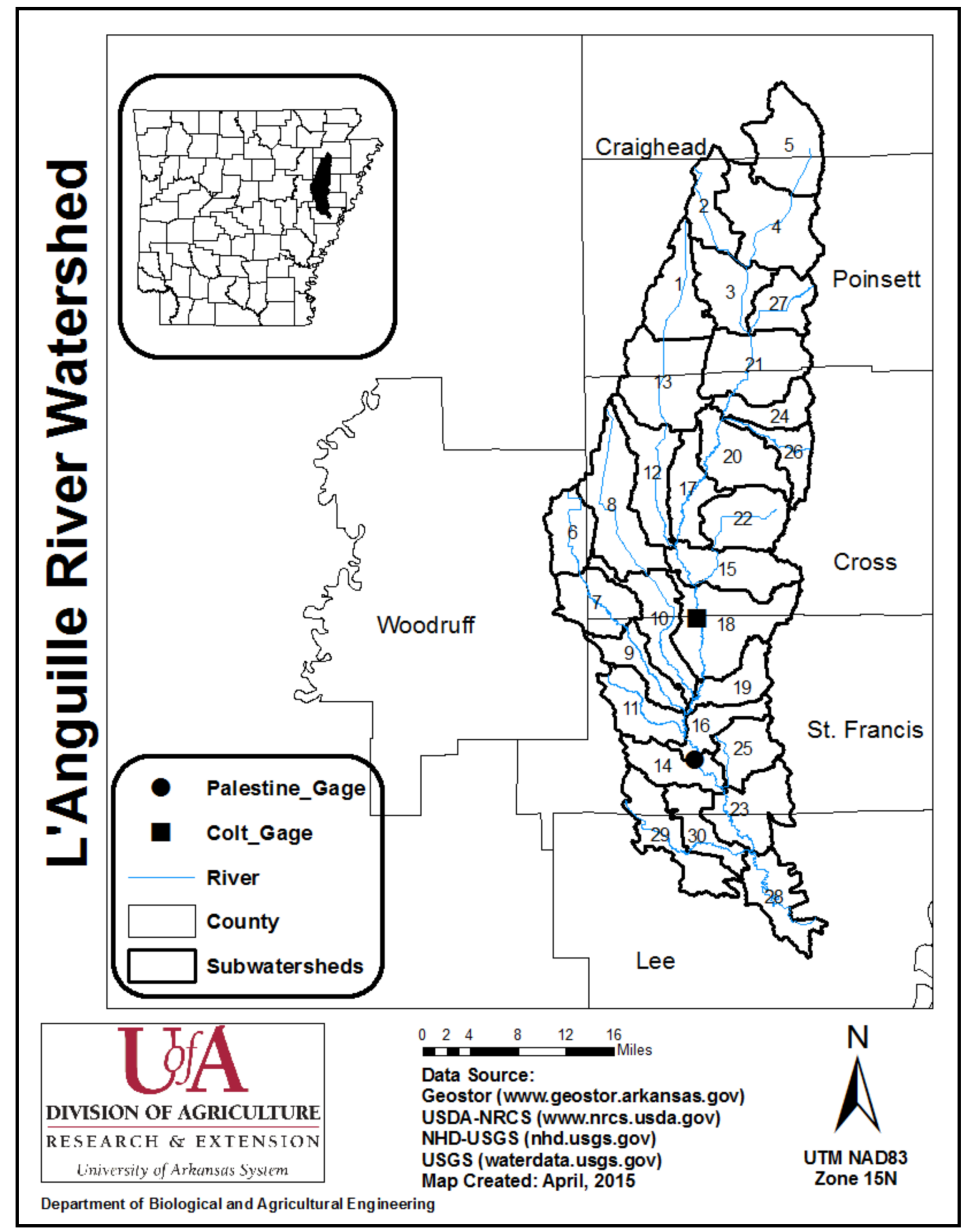

Figure 1. Location of the L'Anguille River Watershed, sub-watershed boundaries, and monitored gauges.

\subsection{SWAT Model Inputs}

SWAT inputs along with their data sources and resolutions are shown in Table 1. The SWAT model (SWAT2012: Revision 627) for the LRW was developed with the ArcSWAT 2012.10_1.15 (July 2014) interface that was compatible with ArcGIS 10.1 version. Studies have indicated better hydrological responses by using Next-Generation Radar (NEXRAD) precipitation data in SWAT [20,21]. As the NEXRAD-SWAT tool (for processing NEXRAD datasets) was not compatible with ArcGIS 10.1, the NEXRAD dataset was processed using ArcGIS 9.3 (Environmental Systems Research Institute, Redlands, CA, USA). Management practices for the crops grown in the LRW were obtained for each county from the research verification reports published by the University of Arkansas Cooperative Extension Service and have been reported by Singh [22]. These practices were incorporated in the SWAT model by modifying the management operations table in the ArcSWAT interface.

The use of multiple temporal land uses has shown improved spatial and temporal hydrological responses from the SWAT model [23]. Land use changes have also been reported to mask water quality improvements resulting from the implementation of CPs in a watershed [24]. This study used multiple temporal land use/land cover (LULC) data from two different sources-the Center for Advanced Spatial Technologies (CAST) and the National Land Cover Dataset (NLCD) [25,26]. To obtain a common land use classification for all of the LULC data, the LULC categories in the CAST and NLCD data were merged following an approach detailed by Pai and Saraswat [27] (Table 2).

The land-use data in the NLCD included the presence of wetland, whereas the CAST land-use data lacked this information. It is known that wetlands may alter the hydrologic cycle of a watershed [28]. Due to the large area of the LRW under wetlands (about 10\% of the LRW area), and considering its 
importance in impacting nutrient flows, it was decided to utilize default wetland processes for the "WETL" land-use category in the SWAT. For this purpose, wetland information in the CAST data was incorporated from the NLCD data through image processing techniques. Wetlands classified in the 1992 NLCD data (9\% of the watershed area) and 2001 NLCD data (10\% of the watershed area) occupied more or less the same spatial area. Wetland information in the 1999 CAST data was derived from the 1992 NLCD data, and in the 2004 and 2006 CAST data was derived from the 2001 NLCD data. The percentage of watershed area occupied by the wetlands in the CAST data before and after the wetland incorporation is shown in Table 3. For instance, 1999 CAST land use data had 0\% area (i.e., no wetland) before, and $9 \%$ of wetland area after the incorporation process.

Table 1. Model inputs for the L'Anguille River Watershed.

\begin{tabular}{cl}
\hline Input Data & \multicolumn{1}{c}{ Description } \\
\hline Elevation & 10-m resolution (geostor.arkansas.gov; 2006) \\
\hline Slope & Classes $(0-3 \%, 3-8 \%, 8-12 \%$, and $>12 \%)$ (geostor.arkansas.gov; 2006) \\
\hline Watershed Boundary & $1: 24000$ (datagateway.nrcs.usda.gov; 2014) \\
\hline Stream Network & 1:24000 (nhd.usgs.gov; 2014) \\
\hline Soil & Soil Survey Geographic Database (datagateway.nrcs.usda.gov; 2005) \\
\hline Land Use & 28.5 m (www.cast.uark.edu; 1999, 2004, 2006) and \\
\hline 30 m (www.mlrc.gov; 1995, 2001) \\
\hline Meteorological & $\begin{array}{l}\text { Rain gage (gis.ncdc.noaa.gov; 1995-2012) and Next-Generation Radar } \\
\text { (noaa.gov; Apr1996-2012) }\end{array}$ \\
\hline Point Source & Municipal and industrial (http:/ /www.adeq.state.ar.us/; 1992-2012) \\
\hline Management Practices & $\begin{array}{l}\text { Row crops, pasture, forestry, and urban practices (http://www.uaex.edu/ } \\
\text { farm-ranch/crops-commercial-horticulture/verification.aspx; 1995-2012) }\end{array}$ \\
\hline
\end{tabular}

Table 2. Land-use and land-cover merged categories for the Center for Advanced Spatial Technologies (CAST) and National Land Cover Datasets (NLCD) layers (Reproduced from Pai and Saraswat [27]).

\begin{tabular}{ccc}
\hline Agency (Year) & Category Name & Merged Name \\
\hline \multirow{3}{*}{ CAST $(1999,2004,2006)$} & Intensity 1 and Urban (other) & Urban low intensity \\
& Intensity 2 and Intensity 3 & Urban high intensity \\
& Various types of trees (oak, pine, etc.) & Forest \\
& Warm season and cool season grasses & Pasture \\
\hline \multirow{2}{*}{$\operatorname{NLCD}(1992,2001)$} & Low /High residential or recreational & Urban low intensity \\
& Commercial, industrial, transportation & Urban high intensity \\
& Deciduous, evergreen, mixed & Forest \\
\hline
\end{tabular}

Table 3. Transformation of wetland in CAST and cultivated crop in NLCD land-use layers.

\begin{tabular}{cccc}
\hline Land Use Layers & $\begin{array}{c}\text { Land Use } \\
\text { Types }\end{array}$ & $\begin{array}{c}\text { Before Wetland Incorporation } \\
\text { (or Enhancement) } \\
\text { (\% of Watershed Area) }\end{array}$ & $\begin{array}{c}\text { After Wetland Incorporation } \\
\text { (or Enhancement) } \\
\text { (\% of Watershed Area) }\end{array}$ \\
\hline 1999 CAST & Wetland & 0 & 9 \\
2004 CAST & Wetland & 0 & 10 \\
2006 CAST & Wetland & 0 & 10 \\
\hline 2001 NLCD & Cultivated & 73 (general crop category) & 11 (general crop category) + \\
& Crop & & \\
\hline
\end{tabular}

NLCD 1992 and 2001 data did not provide a break-up of locations under different crops (such as corn, soybean, etc.); rather, it included only a general category that was referred to as "cultivated 
crops" [26]. Therefore, the LULC data was enhanced by the incorporation of specific cultivated crop-related information in the NLCD data from cropland data layers (CDL). The percentage of watershed area occupied by cultivated crops in the NLCD data before and after the enhancement process was implemented is shown in Table 3. For instance, the 2001 NLCD land use data had 73\% cultivated crops before the enhancement process, and $11 \%$ cultivated crops after the enhancement process, resulting in $62 \%$ of the cultivated crop split into different crops. As there are no CDL layers available for 1992, the cultivated crop category in the NLCD1992 data was not subjected to the enhancement.

\subsection{Model Specifics}

A user-defined approach was used in this study to generate sub-watershed boundaries that matched 12-digit HUC boundaries as defined by the United States Geological Survey (USGS). Although commonly-used thresholds range from $5 \%$ to $15 \%$ [16], there are no available guidelines specifying what or if thresholds for land use, soil, and slope, should be selected for water quality assessment studies. However, as per the recommendation of Her, Frankenberger, Chaubey, and Srinivasan [16], the model was set up with $0 \%$ thresholds for land use, soil, and slope in order to not lose any spatial information in the watershed while estimating the water quality impacts of the implemented CPs. The use of no thresholds resulted in 10,561 HRUs that were simulated using the supercomputer facility at the University of Arkansas and a 64-bit processor with 16 GB random access memory (RAM) memory. SWAT input files in text file format were transferred to the supercomputing facility. A secure shell client (SSH) was used to connect the supercomputing nodes to the desktop computer. The SWAT source code was compiled into a Linux executable. The SWAT model was run with the help of a Portable Batch System (PBS) file. Calibration at the supercomputing facility reduced the SWAT run time to one-third of the time required on the desktop computer.

\subsection{Phosphorus Initialization}

The soil P routines in the SWAT model simulate three inorganics (active, solution, and stable), and two organic pools (fresh and humic) [15]. Since the soil P data for the LRW were not available, fixed amounts of soil P pools for each HRU were initialized in SWAT and treated as a calibration value. Though the inclusion of a warm-up period before model calibration tends to stabilize nutrient pools, the selection of initial values for various nutrient pools has not been discussed much in the literature. The approach reported by Vadas and White [29] was adopted to initialize the solution P and P sorption coefficient (PSC) parameters in SWAT by using the existing soil chemical data.

A long-term soil test dataset was obtained from the University of Arkansas Soil Testing and Research Laboratory for three counties (Craighead, Cross, and Lee) within the LRW. As the exact location of the samples was not available, the data was aggregated on a county basis, and it was assumed to be representative of all of the soils in the sub-watersheds in that county. As the Mehlich-3 soil test method was used for obtaining the soil $\mathrm{P}$ concentrations $[30,31]$, the approach recommended by Vadas and White [29] was used to initialize the soluble P (Sol_P) pool of the SWAT model from Mehlich-3 extractable soil P concentrations. Using this approach, the final Sol_P values selected for the initial soil P levels for the Craighead (sub-watershed 5), Cross (sub-watersheds 7, 8, 12, 15, 17, 20, 22, 24 , and 26), and Lee (sub-watersheds 28,29 , and 30) counties were calculated to be $37.4 \mathrm{mg} / \mathrm{kg}, 22.2$ $\mathrm{mg} / \mathrm{kg}$, and $34.2 \mathrm{mg} / \mathrm{kg}$, respectively.

Another parameter-PSC, which is a watershed-scale parameter-was estimated based on the equations presented in Sharpley, Jones, Gray, and Cole [32]. These equations provided PSC values for calcareous, highly weathered, and slightly weathered soils. In the LRW, the three major soil groups present were Henry, Calloway, and Zachary. The suborder of Henry, Calloway, and Zachary were 
Aqualfs, Udalfs, and Aqualfs, respectively. All of these suborders fall within the Alfisols order, which is highly weathered. For highly weathered soils, the PSC was estimated using Equation (1) [29]:

$$
\mathrm{PSC}=-0.053 \times \ln (\% \text { clay })+0.001 \times\left(\text { Solution } \mathrm{P}, \mathrm{mg} \mathrm{kg}^{-1}\right)-0.029 \times(\% \text { Organic } \mathrm{C})+0.42
$$

The \%Clay and \%Organic $\mathrm{C}$ in the top layer was averaged for the top three soils groups obtained from the soil survey geographic datasets. The Sol_P value used in Equation (1) was obtained by averaging the calculated values for Craighead, Cross, and Lee Counties, as reported in the previous paragraph. Thus, the estimated PSC value was calculated to be 0.29 , and was used in the SWAT model for initializing the P pools.

\subsection{Calibration and Validation}

The SWAT model was set up from 1995 to 2012, with three years as a warm-up period. The calibration period was from 1998 to 2005, and the validation period from 2006 to 2012. The model was calibrated and validated for flow, sediment, total phosphorus (TP), and nitrate nitrogen (NO3-N). A flowchart for the calibration methodology developed by Santhi, Arnold, Williams, Dugas, Srinivasan, and Hauck, [33] and revised by Engel, Storm, White, Arnold, and Arabi [34] was further revised in this study (Figure 2).

A standalone tool, SWAT-Check, was used to read the selected SWAT outputs and alert for common model application errors [35]. SWAT-Check was used before and during the calibration process to resolve potential warnings in the model, which were mostly related to the hydrological and $\mathrm{N}$-cycle processes. Latin hypercube sampling and the one factor-at-a-time method were used to conduct sensitivity analysis. The SWAT model was calibrated and validated at a monthly time-step for the Colt and Palestine USGS sites. Manual calibration was used to adjust the parameters to better represent the measured data. The objective functions used to optimize flow, sediment, TP, and NO3-N were the coefficient of determination $\left(\mathrm{R}^{2}\right)$, Nash-Sutcliffe efficiency (NSE), percent bias (PBIAS), and root mean square error-standard deviation ratio (RSR). The established model performance criteria proposed by Santhi, Arnold, Williams, Dugas, Srinivasan, and Hauck [33] for $\mathrm{R}^{2}$ and Moriasi, Arnold, Van Liew, Bingner, Harmel, and Veith [36] for NSE, PBIAS, and RSR were used to evaluate the model.

The measured datasets for flow, sediment, TP, and NO3-N were obtained from the USGS website (waterdata.usgs.gov/nwis). Information about the drainage area and data duration at Colt and Palestine are reported in Table 4. The flow data was split into surface and base flow using the base flow filter program. The Load Estimator (LOADEST) tool was used to obtain continuous monthly values for sediment, TP, and NO3-N at the Colt site. The LOADEST software was developed by USGS, and has been used by many researchers $[37,38]$. The adjusted maximum likelihood estimation (AMLE) was used in LOADEST, as it assumes that the samples are normally distributed with a constant variance, and generates a nearly unbiased estimate of instantaneous load, even for the censored data (data censoring occurs when there are one or more observations with constituent concentrations less than the laboratory detection limit) [39]. There were 325, 85, and 89 observations available for sediment, TP, and NO3-N. Model 9 was selected for the sediment load estimations, and model 1 was selected for the TP and NO3-N load estimations based on Akaike Information Criterion. The regression in model 9 explained $>83 \%$ of the variability in the sediment loads, and the regression in model 1 explained $>90 \%$ and $>72 \%$ of the variability in the TP and NO3-N loads, respectively, indicating a good model fit. The $\mathrm{p}$-values for the regression coefficients were statistically significant for sediment, TP, and NO3-N $(p<0.05)$, except for the sediment a4 coefficient $(p=0.3)$, indicating that the changes in the predictor's value are related to the changes in the response variable. To further assess how well LOADEST is predicting the concentrations of each constituent, daily LOADEST load estimations were converted to concentrations, and compared with the available observed values. The correlation coefficients between the estimated and measured concentrations were $0.60,0.65$, and 0.56 for the sediment, TP, and NO3-N, indicating a good model fit. The LOADEST tool was not used for obtaining sediment and nutrient 
estimates at a monthly time-step at Palestine due to an insufficient number of water quality samples (only seven) available from October 1998 to December 2012.

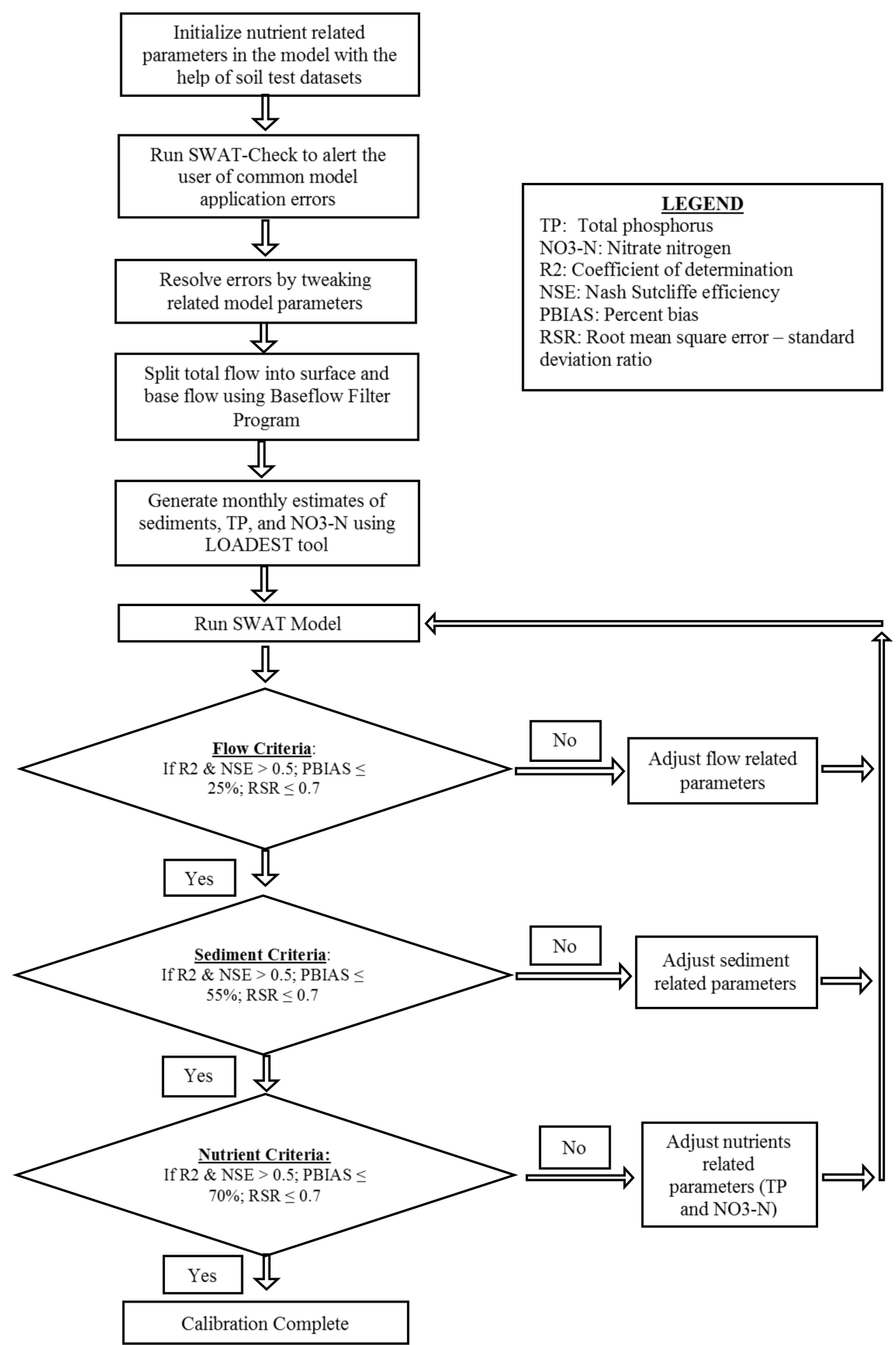

Figure 2. Flowchart depicting the revised calibration process at the monthly time step (modified from Engel, Storm, White, Arnold, and Arabi [34]). 
Table 4. Measured data sites in L'Anguille River Watershed (LRW).

\begin{tabular}{cccccc}
\hline Gage No. & Location & $\begin{array}{c}\text { Drainage } \\
\text { Area (sq. km) }\end{array}$ & Agency Data Providing & $\begin{array}{c}\text { Flow Data } \\
\text { Duration }\end{array}$ & $\begin{array}{c}\text { Water Quality } \\
\text { Data Duration }\end{array}$ \\
\hline 07047942 & Colt & 503 & USGS (http://www.usgs.gov/) & $1995-2012$ & $1995-2012$ \\
\hline 07047950 & Palestine & 784 & USGS (http://www.usgs.gov/) & $1998-2012$ & $1998-2012$ \\
\hline
\end{tabular}

\subsection{Selected CPS}

Based on the ability of the SWAT model to simulate CPs, seven MRBI-recommended CPs were simulated in the SWAT model that was developed for the LRW: filter strip, critical area planting, grade stabilization structure, irrigation land leveling, irrigation pipeline, irrigation water management, and nutrient management. Selected CPs were simulated by changing the relevant parameters in SWAT to represent specific processes relating to the CPs in the model to assess impacts on sediment, TP, and total nitrogen (TN) transport.

A filter strip represents a strip of permanent vegetation that is established at the edge or around the perimeter of a field [40]. This practice applies to cropland and grazing lands. Lacking specific information from the LRW, filter strips were simulated in the SWAT model using the default parameters for the in-built filter strip module in ArcSWAT (i.e., FILTER_RATIO $=40$, FILTER_CON $=0.5$, and FILTER_CH =0).

Critical area planting represents establishing permanent vegetation on sites that have high erosion rates or have physical, chemical, or biological conditions preventing the establishment of vegetation with normal practices [41]. Critical area planting was simulated by replacing barren lands with pasture areas in good condition [42]. The area under the barren land-use class could comprise of a variety of landscape components; therefore, it was carefully examined using historical aerial imagery to ensure that the bare areas shown in the imagery were included under this category. Such examination was helpful in the accurate characterization of barren land HRUs. In this watershed, a majority of the barren area was found to be historically under minimal vegetative cover.

A grade stabilization structure represents a structure controlling the grade and head cutting in channels [43]. SWAT estimates sediment yield and erosion with the modified universal soil loss equation (MUSLE) and determines transport concentration capacity as a function of flow velocity by the modification of Bagnold's sediment transport equation. Grade stabilization structures were simulated by defining the slope steepness of channels [(CH_S(2)] parameter in SWAT as 20\% of the actual slope [42].

Irrigation land leveling represents reshaping irrigated land surfaces to planned grades [44]. This practice was applied to all of the lands where irrigation has been applied. Irrigation land leveling was simulated by reducing the HRU slope (reducing HRU_SLP parameter by 10\%) and slope length (reducing SLSUBBSN parameter by one-tenth of the default value) [45].

An irrigation pipeline represents a pipeline installed to convey water for storage or application, as part of an irrigation water system [46]. This practice was also applied to all of the lands where irrigation has been applied. An irrigation pipeline was simulated by increasing the conveyance efficiency of the HRU from 0 to 5 (IRR_EFM in the management operation table) [45].

Irrigation water management represents controlling the rate, amount, and timing of irrigation water in an efficient manner [47]. Similar to irrigation land leveling and irrigation pipelines, this practice was also applied to all of the lands where irrigation has been applied. Irrigation water management was simulated by adjusting the water volume required for irrigation with respect to the seasonal total rainfall received (planting to harvest date) [45]. The water application rate was adjusted based on the quantity and the timing of rainfall using the method described by Kannan, Jeong, and Srinivasan [45].

Nutrient management represents managing the amount (rate), source, placement (method of application), and timing of plant nutrients and soil amendments [48]. This practice was applied to all of the lands where plant nutrients and soil amendments were applied. In this study, a more restrictive 
application scenario of nutrient management was simulated by reducing fertilizer inputs by $50 \%$ of the pre-CP scenario. Several SWAT model studies have also reported a $50 \%$ fertilizer reduction scenario [49-51]; therefore, this study was designed to further the results reported by past studies.

\section{Results}

\subsection{Calibration and Validation Results}

Water balance is the major driving force behind all of the processes in SWAT, as it impacts plant growth as well as movement of sediments, nutrients, pesticides, and pathogens. SWAT simulates watershed hydrology into the land phase, controlling the amount of water, sediment, nutrient, and pesticide loadings to the main channel in each sub-watershed, and the in-stream phase, controlling the movement of water, sediments, etc., through the channel network of the watershed to the outlet. More details of these processes can be found in the SWAT theoretical documentation [52]. To evaluate the initial model performance, an overall annual water balance was calculated at the watershed scale using the basin level output (output.std). The water balance was calculated with the help of Equation (2).

$$
\begin{gathered}
\text { Precipitation }=\text { Surface runoff }+ \text { Groundwater Discharge }+ \\
\text { Evapotranspiration }(\text { ET })+\text { Deep Aquifer Recharge }
\end{gathered}
$$

To evaluate water balance, both sides of the above equation were expected to be similar over a long simulation period. This was verified using simulations from 1998 to 2005 (calibration time period) at an annual scale. The sum of surface runoff (343 mm), groundwater discharge (165 mm), evapotranspiration $(512 \mathrm{~mm})$, and aquifer recharge $(122 \mathrm{~mm})$ accounted for $\sim 100 \%$ of the precipitation (1145 $\mathrm{mm})$, and the small difference being the change in the soil water content; hence, the water balance of the watershed was considered satisfactory. The sum of simulated groundwater (165 mm) and lateral flow $(10 \mathrm{~mm})$ contributed $37.8 \%$ of the total water yield $(463 \mathrm{~mm})$, which is similar to the base flow estimated at the USGS gage at Colt (38\%). Precipitation in the watershed ranged from $1105 \mathrm{~mm}$ to $1275 \mathrm{~mm}$ per year during the modeling period against an average annual precipitation of $1141 \mathrm{~mm}$.

SWAT-Check warnings, as well as their potential resolutions, are reported in Table 5. The warnings were related to the hydrology, N-cycle, plant growth, and point sources sections of the SWAT-Check tool. Once warning issues were resolved, the sensitivity analysis was conducted to identify the parameters that could be used for model calibration. The five most sensitive parameters for flow, sediment, TP, and NO3-N are listed in Table 6. Some parameters (not identified as sensitive parameters) were selected to make a better fit for the measured and simulated data [33].

Table 5. SWAT-Check messages/warnings and potential resolution for the LRW Soil and Water Assessment Tool (SWAT) model.

\begin{tabular}{ll}
\hline \multicolumn{1}{c}{ Warnings } & \multicolumn{1}{c}{ Resolution } \\
\hline Water yield may be excessive $1:$ Hydrology & $\begin{array}{l}\text { This warning appears mostly when the evapotranspiration simulated in the } \\
\text { uncalibrated model is low. Evapotranspiration-related parameters such as } \\
\text { soil evaporation compensation factor should be modified during calibration } \\
\text { to resolve this warning. }\end{array}$ \\
\hline $\begin{array}{l}\text { Senitrification is zero, } \\
\text { consider decreasing } \\
\text { denitrification threshold } \\
\text { water content }\end{array}$ & $\begin{array}{l}\text { This warning appears when the parameters dictating the start of } \\
\text { denitrification (denitrification threshold water content - SDNCO and } \\
\text { denitrification exponential rate coefficient - CDN) are zero. As a result, } \\
\text { these two denitrification parameters should be adjusted during calibration } \\
\text { to initiate the process of denitrification in the model. }\end{array}$ \\
\hline
\end{tabular}


Table 5. Cont.

\begin{tabular}{ll}
\hline \multicolumn{1}{c}{ Warnings } & \multicolumn{1}{c}{ Resolution } \\
\hline $\begin{array}{l}\text { Unusually low phosphorus } \\
\text { stress }\end{array}$ & $\begin{array}{l}\text { The models nutrient balance was functioning properly, and as P was added } \\
\text { during the crop management practices, this warning was dismissed [53]. }\end{array}$ \\
\hline $\begin{array}{l}\text { Inlet/point sources contribute } \\
\text { flow but not phosphorus }\end{array}$ & $\begin{array}{l}\text { This warning appears when no P loading is reported in the point source } \\
\text { data received from the relevant agency (in this case Arkansas Department } \\
\text { of Environmental Quality and Environmental Protection Agency). }\end{array}$ \\
\hline $\begin{array}{l}\text { Inlet/point sources contribute } \\
\text { flow but not nitrogen }\end{array}$ & $\begin{array}{l}\text { This warning appears when no N loading is reported in the point source } \\
\text { data received from the relevant agency (in this case Arkansas Department } \\
\text { of Environmental Quality and Environmental Protection Agency). }\end{array}$ \\
\hline
\end{tabular}

Table 6. Top five parameters identified as sensitive for flow, sediment, total $\mathrm{P}$, and nitrate-N.

\begin{tabular}{cccccc}
\hline Variable & $\mathbf{1}$ & $\mathbf{2}$ & $\mathbf{3}$ & $\mathbf{4}$ & $\mathbf{5}$ \\
\hline Flow & CN2 & ESCO & SOL_AWC & GWQMN & ALPHA_BF \\
\hline Sediment & USLE_P & SPCON & USLE_C & SPEXP & CH_N2 \\
\hline Total $\mathbf{P}$ & PHOSKD & PPERCO & SURLAG & SOL_Z & SHALLST_N \\
\hline Nitrate-N & RCHRG_DP & NPERCO & CH_K2 & ALPHA_BF & SOL_NO3 \\
\hline
\end{tabular}

CN2 affects the overland flow and was ranked as the most sensitive parameter for flow. The soil evaporation compensation factor (ESCO) was another sensitive parameter for flow, mainly because water balance is sensitive to ESCO. USLE_P was the most sensitive parameter for sediment, which indicated that changes in the land-use practice factor would affect sediment losses. USLE_C was another sensitive parameter affecting sediment, indicating that a change in crop management factors would affect sediment losses. The SPCON, SPEXP, and CH_N2 parameters that impact the channel processes also affected sediment losses, indicating that sediment losses in the LRW were affected by both overland (surface) and channel processes.

PHOSKD was the most sensitive parameter affecting TP. Similar to CN2, PHOSKD was also related to the overland process. As a result, it was observed that the overland processes mostly impacted flow, sediment, and TP in the LRW. RCHRG_DP was the most sensitive parameter for NO3-N, which was expected, as the movement of NO3-N is mainly an underground process.

Parameters adjusted for calibration and validation are shown in Table 7. A detailed description of the parameters is reported in the SWAT2012 Input/Output File Documentation available at http: //swat.tamu.edu/documentation/2012-io/. The parameters were adjusted such that their values were kept within the recommended ranges suggested by SWAT modelers/developers. The statistical calibration and validation results at the Colt and Palestine sites are shown in Table 8, and the temporal results at both of the sites are shown in Figures 3-5. The $\mathrm{R}^{2}$, NSE, and PBIAS were satisfactory or better, indicating a satisfactory goodness of fit; however, RSR was unsatisfactory during the calibration period for sediment, TP, and NO3-N. Since both PBIAS and RSR are error indexes, and PBIAS was satisfactory or better for sediment, TP, and NO3-N, calibration results were assumed as satisfactory.

The PBIAS statistics indicated an overprediction of total flow during the calibration period (negative biases) and underprediction during the validation period (positive biases) at the Colt site (Figure 3). A high underprediction of total flow occurred during March 2002, whereas high overprediction was observed during October 1998 and 1999, June 2000, and May 2004 (Figure 3). In contrast, total, surface, and base flow was overpredicted both during the calibration and validation period (negative biases) at the Palestine site. The only exception of underprediction of total and base flow at the Palestine site was in November 2009 (Figure 4). The underprediction and overprediction is attributed to the SWAT model's inability to simulate a storm event as it is designated for long-term 
simulation. It has been reported that the inability of the input rainfall data to completely reflect the actual spatial variability of rain could lead to errors in predicting flow [33,54]. The other sources that could lead to the overprediction or underprediction of flow comprises of a combination of measurement error, systematic error, model uncertainty, subjective judgment, and inherent randomness [55-57].

Table 7. Parameters adjusted for calibration. HRU: hydrological response units.

\begin{tabular}{cccc}
\hline Variable & Input file & Recommended Values & Final Value \\
\hline CN2 & Management & $35-98$ & $\pm 5 \%$ (Relative change from the baseline) \\
ESCO & HRU & $0-1$ & 0.95 \\
SOL_AWC & Soil & $0-1$ & $0.78-0.82$ (Range across all HRUs) \\
ALPHA_BF & Groundwater & $0-1$ & 0.77 \\
RCHRG_DP & Groundwater & $0-1$ & 0.58 \\
GWQMN & Groundwater & $0-5000$ & 0.2 \\
GW_REVAP & Groundwater & $0.02-0.2$ & 0.03 \\
CH_N2 & Main Channel & $0-0.3$ & 0.08 \\
USLE_P & Management & $0-1$ & 0.80 \\
SPCON & Basin & $0.0001-0.01$ & 0.0016 \\
SPEXP & Basin & $1.0-1.5$ & 1.0 \\
PRF & Basin & $n o n e$ & 0.1 \\
SURLAG & Basin & $1-24$ & 12 \\
SOL_Z & Soil & $0-3500$ & 2032 \\
CH_K2 & Main channel & $0-500$ & 150 \\
PHOSKD & Basin & $100-200$ & 175 \\
PPERCO & Basin & $10.0-17.5$ & 11.0 \\
CDN & Basin & $0-3$ & 3 \\
SDNCO & Basin & $0-1$ & 0.2 \\
NPERCO & Basin & $0-1$ & 0.32 \\
RSDCO & Basin & $0.02-0.1$ & 0.02 \\
SOL_NO3 & Chemical & $0-100$ & 10 for all soil layers \\
SOL_ORGN & Chemical & $0-100$ & 10 for all soil layers \\
BIOMIX & Management & $0-1$ & 0.15 \\
SHALLST_N & Groundwater & $0-1000$ & 5 \\
\hline & & &
\end{tabular}

Table 8. Results for the monthly calibration and validation of the LRW SWAT model.

\begin{tabular}{cccccccccc}
\hline \multirow{2}{*}{ Gauge Site } & \multirow{2}{*}{ Output } & \multicolumn{4}{c}{ Calibration } & \multicolumn{4}{c}{ Validation } \\
\cline { 3 - 9 } & $\mathbf{R}^{2} \mathbf{1}$ & NSE $\ddagger$ & PBIAS $\S$ & RSR & $\mathbf{R}^{2}$ & NSE & PBIAS & RSR \\
\hline \multirow{6}{*}{ Colt } & Total flow & 0.70 & 0.66 & -4.28 & 0.58 & 0.78 & 0.68 & 7.68 & 0.48 \\
& Surface flow & 0.66 & 0.64 & -1.16 & 0.60 & 0.80 & 0.64 & -0.17 & 0.47 \\
& Base flow & & & -3.81 & & & & 21.11 & \\
& Sediment & 0.59 & 0.55 & 46.25 & 0.83 & 0.79 & 0.67 & 23.53 & 0.56 \\
& Total P & 0.58 & 0.52 & 18.25 & 0.89 & 0.84 & 0.72 & 28.30 & 0.44 \\
& Nitrate N & 0.53 & 0.50 & 4.47 & 0.96 & 0.69 & 0.54 & 0.11 & 0.65 \\
\hline \multirow{3}{*}{ Palestine } & Total flow & 0.58 & 0.54 & -7.65 & 0.66 & 0.77 & 0.61 & -13.46 & 0.61 \\
& Surface flow & 0.54 & 0.51 & -10.94 & 0.73 & 0.80 & 0.72 & -20.55 & 0.52 \\
& Base flow & & & -12.57 & & & & -3.09 & \\
\hline
\end{tabular}

† Coefficient of Determination. ‡ Nash-Sutcliffe Efficiency. § Percent Bias. RSR: Root mean square error-standard deviation ratio.

Sediment was underpredicted by SWAT for the calibration and validation period at the Colt site. Sediment underprediction during March 2002 is tied with flow underprediction for the same month (Figure 5). As P binds with sediment and gets transported with it, TP was found to be underpredicted for the calibration and validation period, which was similar to sediment. Overpredicted peaks were observed for NO3-N (October 1999 and November 2004) during the calibration and validation period, while it was found to be underpredicted for February 2002. In general, the calibration of NO3-N is often difficult, resulting in poor simulations [58]. It can also be assumed that errors in baseflow 
predictions were expected to propagate to NO3-N. Overall, the model was considered satisfactory due to the robustness of the multisite, multivariable, and multiobjective calibration and validation strategy.
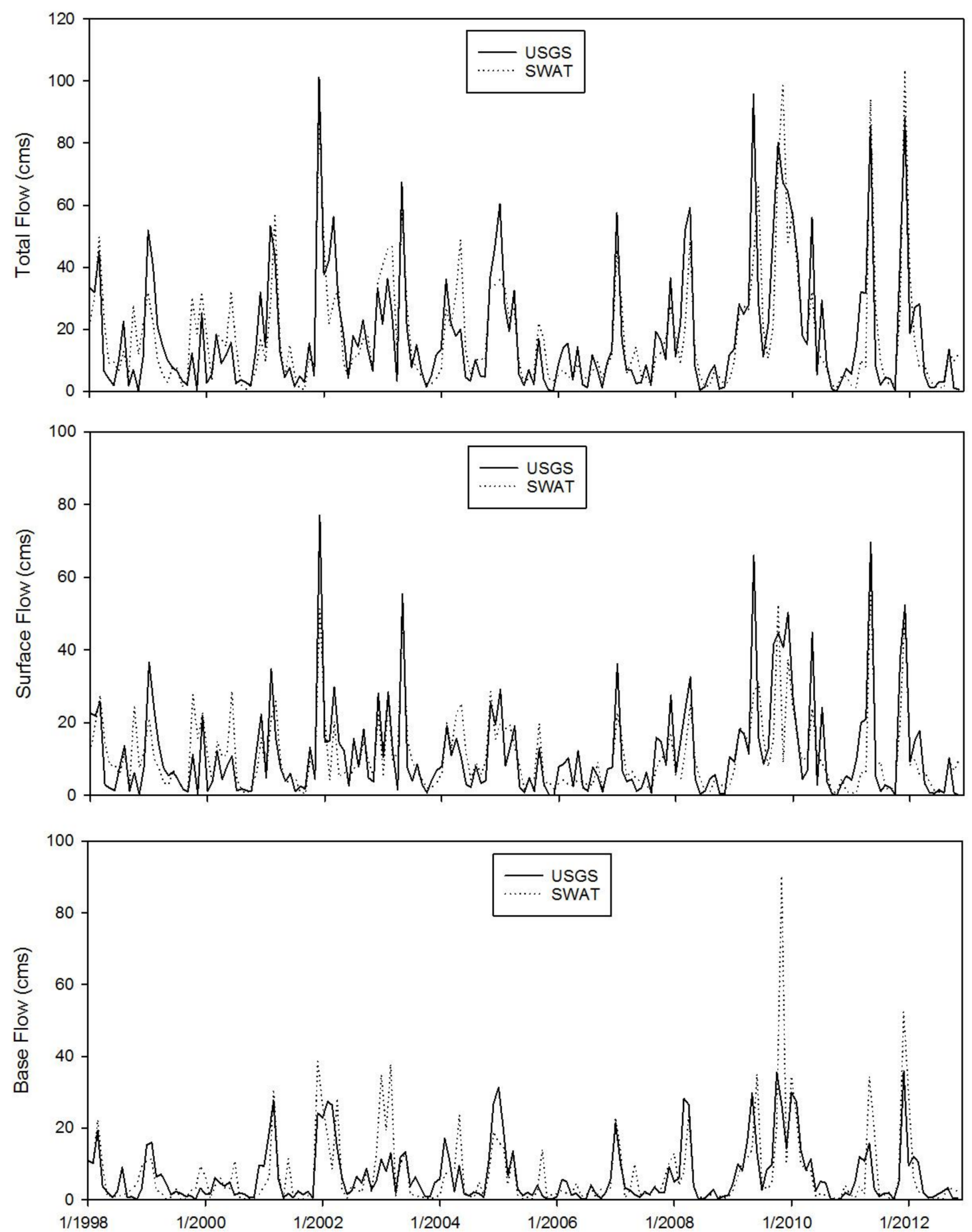

Figure 3. Graphical comparison of the USGS (measured) and SWAT (simulated) flow data at the Colt site. 

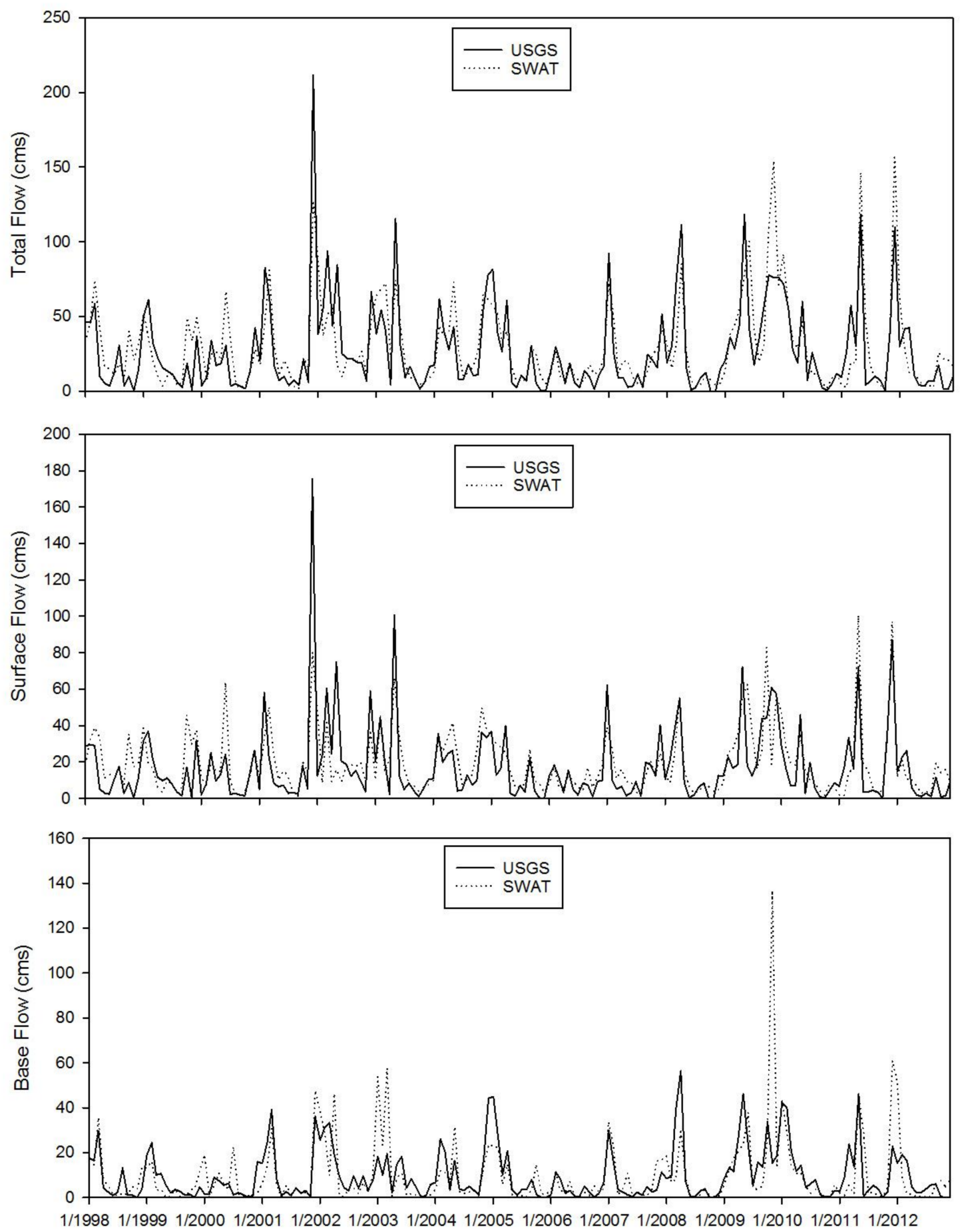

Figure 4. Graphical comparison of the USGS (measured) and SWAT (simulated) flow data at the Palestine site. 

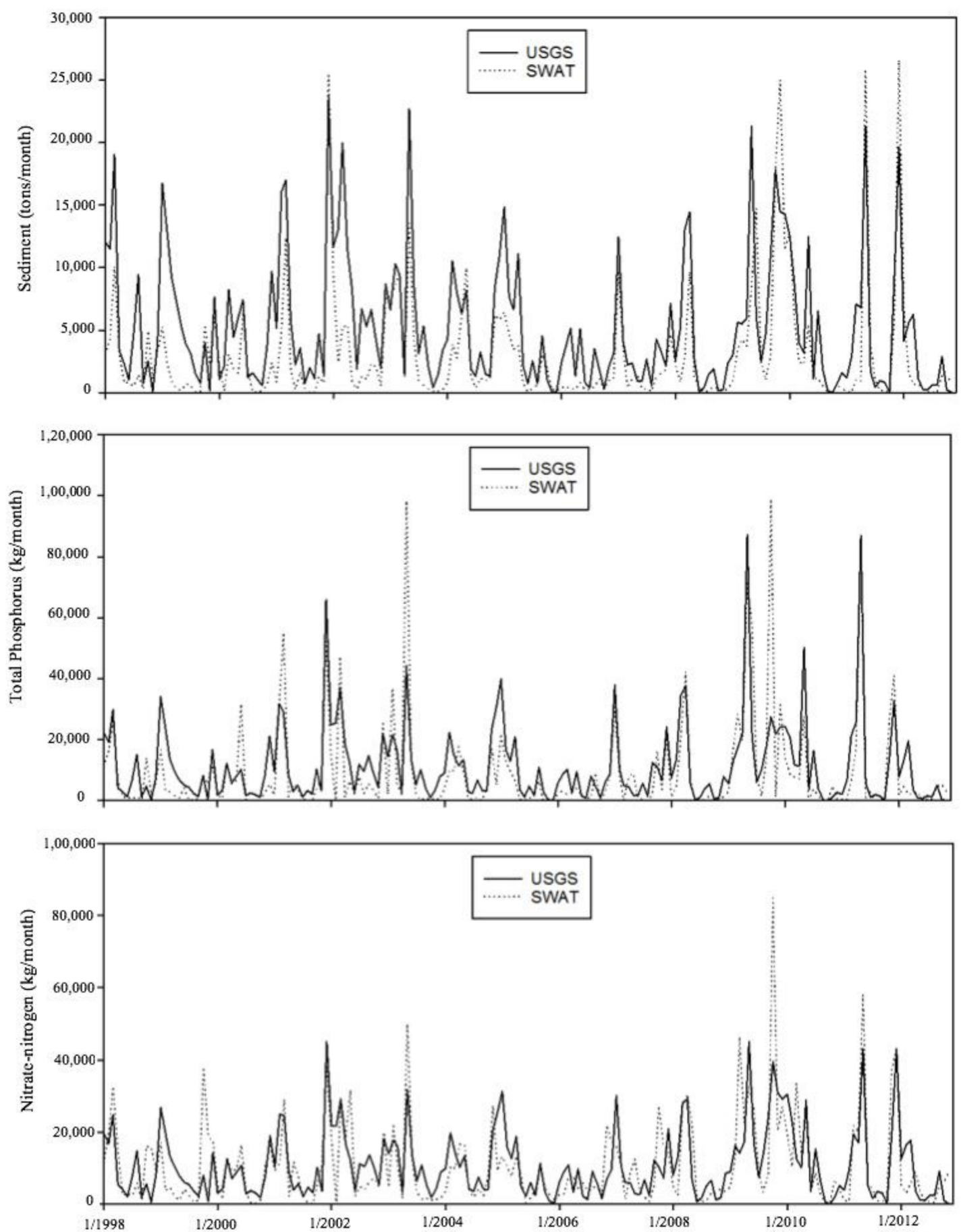

Figure 5. Graphical comparison of the USGS (estimated using the Load Estimator, or LOADEST) and SWAT (simulated) water quality data at the Colt site.

\subsection{Comparison of Pre-CP and Post-CP Scenarios}

Since water quality losses in the near future are of interest, simulations were run for five years (2013 to 2017) past the model calibration and validation period. The statistical weather calculator available in SWAT was used for preparing the projected weather data files. Paired $t$-tests were performed at a monthly scale to test differences between the predicted losses (i.e., sediment, TP, and $\mathrm{TN}$ ) at each HRU comparing pre-CP and post-CP datasets, as well as each pair of CPs. 
It should be noted that the pre-CP scenario reflects no CPs implementation in LRW. For the post-CP scenario, each $\mathrm{CP}$ was simulated separately in SWAT. The simulated average annual sediment and nutrient losses exiting the HRUs from each CP (post-CP) were compared with the pre-CP losses scenario. The relative percentage load reduction associated with the selected CPs compared to the pre-CP scenario is shown in Figure 6. The authors have used a relative comparison criterion where if a $\mathrm{CP}$ has a greater total percentage reduction (sum of the percentage reduction of sediment, total phosphorus, and total nitrogen), then that $\mathrm{CP}$ gets a higher ranking.

In general, filter strips are used to reduce nutrient losses from upland areas of the watershed. It was the most effective $\mathrm{CP}$ in reducing predicted TN loss (40\%), along with second most effective in reducing predicted TP loss (43\%; Figure 6). The filter strip scenario results reported in this study fall within the ranges of sediment, TP, and TN reduction from 22 published studies reported by White and Arnold [59]. Parajuli, Mankin, and Barnes [60] reported 63\% sediment reduction with the target filter strip scenario, which is little higher than what has been observed in this study. Critical area planting was the most effective $\mathrm{CP}$ at reducing predicted sediment $(80 \%)$ and predicted TP loss (58\%), along with the second most effective at reducing predicted TN (16\%; Figure 6). Santhi, Srinivasan, Arnold, and Williams [42] and Tuppad, Santhi, Srinivasan, and Williams [61] also reported high reduction in predicted sediment, TP, and TN losses (98-100\% sediment reduction, $90-99 \%$ TP reduction, $82-99 \%$ TN reduction) with the critical area planting scenario.

As grade stabilization structures work to increase deposition in upstream channel reaches, these structures were most effective where channel degradation causes erosion and deteriorate water quality. Grade stabilization structures decreased predicted sediment loss (36\%) to a relatively greater extent than predicted TP $(5 \%)$ and predicted TN (2\%; Figure 6). Tuppad, Santhi, Srinivasan, and Williams [61] and Arabi, Frankenberger, Engel, and Arnold [62] also reported high reduction in sediment (71-74\%) with a grade stabilization structure scenario.

Irrigation land leveling resulted in a decrease in the HRU slope and slope length, which in turn influenced surface transport processes. As sediment and $\mathrm{P}$ are affected the most by surface processes, with $\mathrm{N}$ transport mainly a subsurface flow process, irrigation land leveling was more effective in reducing predicted sediment (52\%; second most effective among CPs) and predicted TP $(37 \%)$ loss compared with predicted TN (7\%) loss. Kannan, Omani, and Miranda [63] also found a higher percentage of sediment reduction (42.4\%) compared with TP and TN reduction, with the simulation of irrigation land leveling $\mathrm{CP}$.

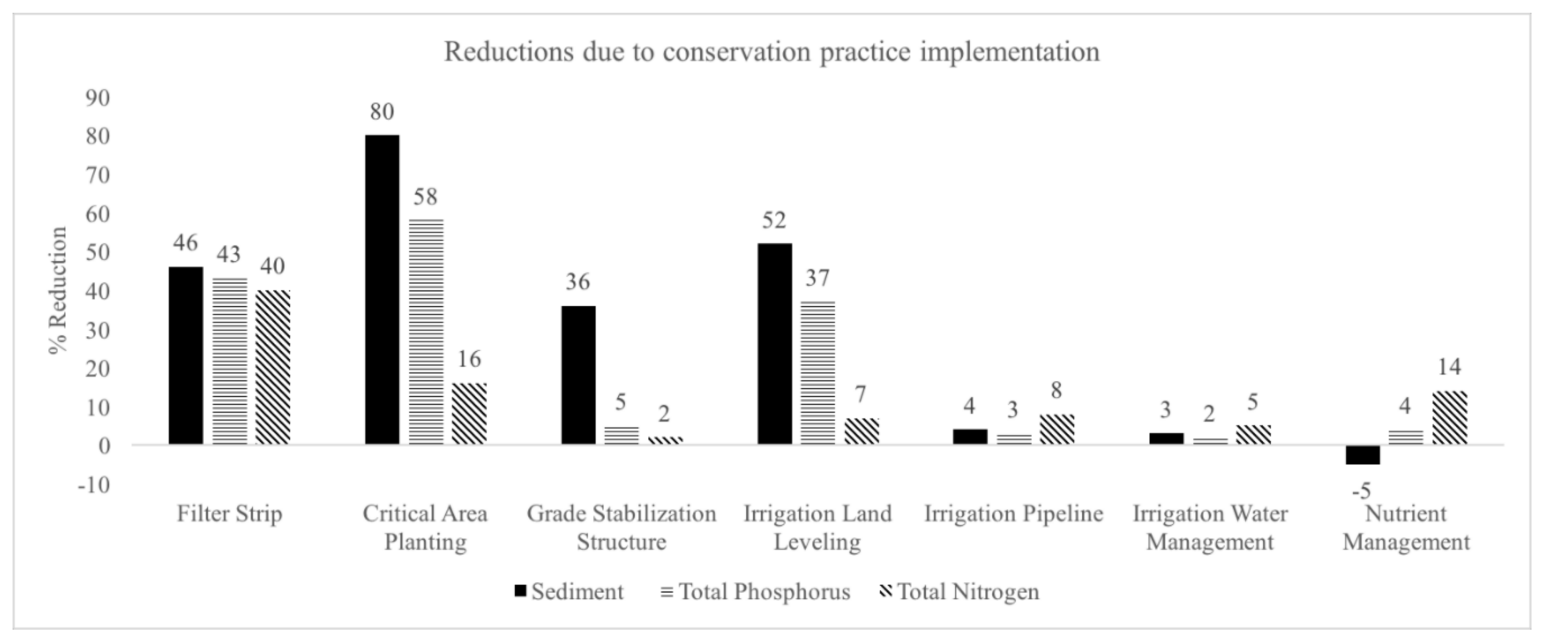

Figure 6. Percentage reductions in sediment and nutrient losses due to simulation of CPs.

Irrigation pipeline, irrigation water management, and nutrient reduction CPs were found to be less effective in decreasing nutrient and sediment loading in the LRW compared to other selected CPs. 
Irrigation pipeline CPs reduced sediment, $\mathrm{TP}$, and $\mathrm{TN}$ by $4 \%, 3 \%$, and $8 \%$, respectively; and irrigation water management by 3\%, 2\%, and 5\%, respectively. Kannan, Omani, and Miranda [63] also reported similar results-a reduction of 3\% in sediment, $4.3 \%$ in $\mathrm{TP}$, and $11.9 \%$ in $\mathrm{TN}$ with the simulation of irrigation CPs.

Nutrient reduction decreased TP and TN loss by $4 \%$ and $14 \%$, respectively, but increased sediment loss slightly (5\%; Figure 6) compared with pre-CP losses. This reduction in $\mathrm{N}$ and $\mathrm{P}$ losses with the adoption of nutrient reduction is consistent with this $\mathrm{CP}$ functioning to decrease the rate of nutrients applied, and at a time when there is a lower risk of runoff or leaching. The slight increase in sediment loss compared with the pre-CP with nutrient reduction may have resulted from lower crop yields as a consequence of lower $\mathrm{N}$ and $\mathrm{P}$ applications (5\%; Figure 6). The lower crop yields (overall $8 \%$ reduced yield) likely resulted in less vegetative cover, and thus more erodible exposed soil surfaces. This yield reduction was contrary to the expected impact of properly applied nutrient reduction, which is intended to eliminate excess nutrient application, not to reduce yield [64].

In summary, the variability in $\mathrm{CP}$ performance in this study supports previous reports that $\mathrm{CP}$ effectiveness is dependent on watershed characteristics, placement strategy, and CP type $[61,65,66]$.

The overall effectiveness of CPs in decreasing order were: critical area planting, filter strip, irrigation land leveling, grade stabilization structure, irrigation pipeline, nutrient reduction, and irrigation water management. A paired $t$-test was performed at a monthly scale to evaluate differences between predicted losses at each HRU and compare pre-CP and post-CP datasets, and it suggests significant differences $(p<0.05)$ in sediments and nutrient loadings. In addition, paired $t$-tests between losses from each pair of CPs also revealed significant differences $(p<0.05)$.

Cumulative nutrient and sediment loss curves were developed at the HRU level to visualize the effectiveness of CPs (Figure 7). Only one CP, i.e., irrigation land leveling, is shown in Figure 7 for sediment, TP, and TN. White, Storm, Busteed, Stoodley, and Phillips [67] presented several such curves to show sediment and nutrient losses variation with respect to the HRU area. The cumulative nutrient and sediment curves were sorted with respect to the contributing watershed area (HRU area). The contributing watershed area (\%) was arranged in ascending order, and sediment and nutrient losses (tons or $\mathrm{kg}$ ) were plotted with respect to the contributing watershed area. This allowed the comparison of pre-CP and post-CP loss from the same HRU (Figure 7). It is evident that cumulative sediment, TP, and TN loss with CPs in place was less than that with no CPs for the same contributing watershed area. For instance, the post-CP sediment losses were approximately 35,000 tons compared to the pre-CP sediment losses of approximately 75,000 tons. As the contributing watershed area increased, the difference in loadings between with and without the $\mathrm{CP}$ scenario became larger for sediment than TP and TN (Figure 7). The trend for TP was similar to that of sediment, because of the ability of $P$ to bind and transport with sediments. Moreover, sediment and TP are dominated by surface processes, as opposed to TN, which is dominated by underground processes. The reductions obtained were higher for sediments (52\%), followed by TP (37\%) and TN (7\%). Kannan, Omani, and Miranda [63] also reported that the sediment reduction from irrigation land leveling $\mathrm{CP}(42 \%)$ was higher than that obtained by $\mathrm{TN}(35 \%)$. 

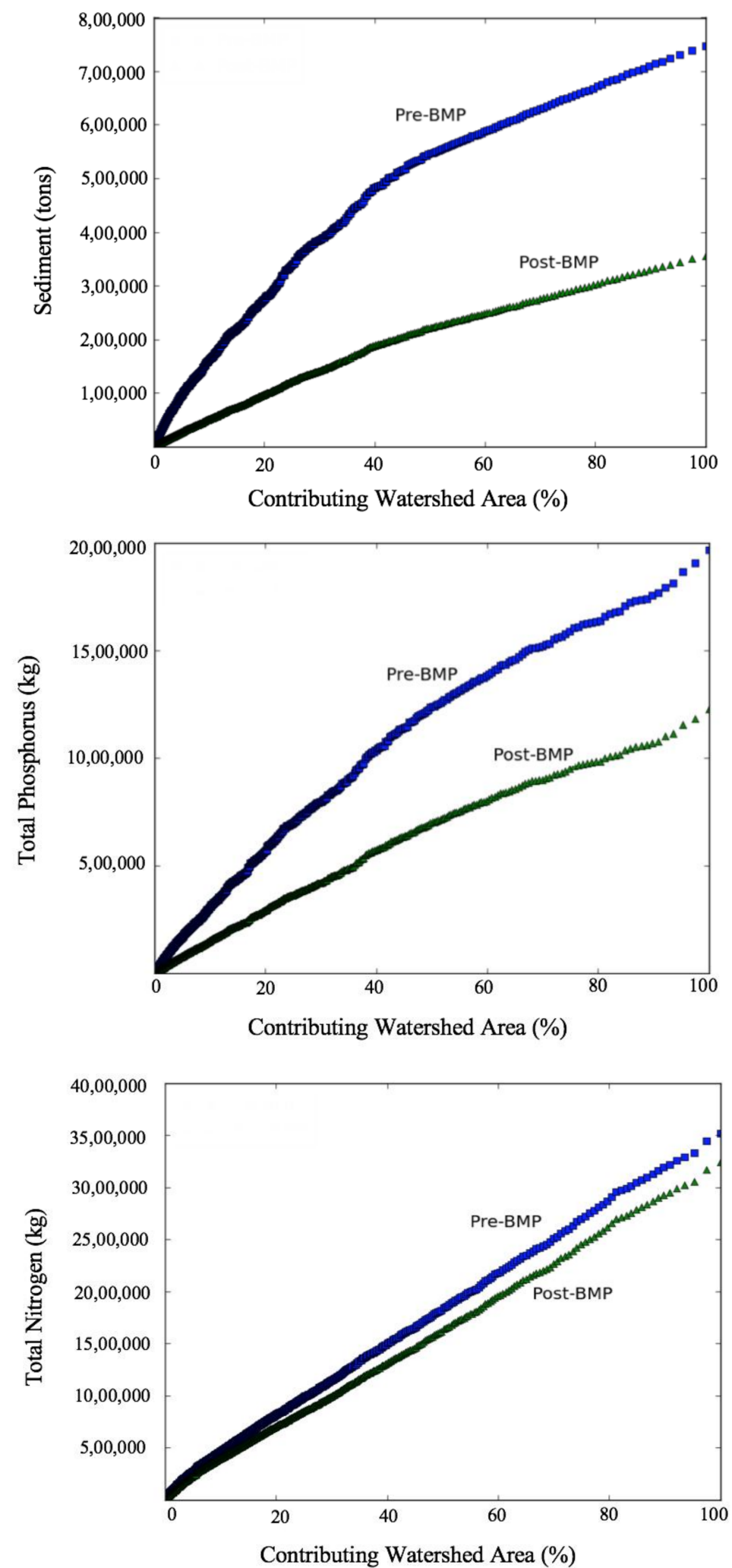

Figure 7. Cumulative sediment (top), Total P (middle), and Total N (bottom) losses by percent of the contributing watershed area for irrigation land leveling scenarios. 


\section{Discussion}

\section{Challenges in Modeling CPS}

Although various CPs have been modeled with SWAT in this study, it is imperative to understand the weaknesses that are associated with their simulation in the model. For example, during filter strip simulation, the filter strip placement and effectiveness throughout an HRU could vary, but a unique representation of filter strips by the default parameters does not allow capturing this variability. Also, the SWAT model lacks spatial realism for filter strips, as it is not possible to identify the exact location of the filter strips in the model.

Pasture was simulated on all of the barren areas for defining critical area planting in this study. However, some barren areas, such as rocky or eroded land, might not be suitable for healthy pasture establishment. Moreover, critical area, which is similar to marginal land, can be defined in various ways, such as based on soil health, current land use, environmental degradation [68], and land capability classes [69]. As a result, the definition of critical area might vary, as per the intended purpose of the studies.

Grade stabilization structures were represented in the model by reducing the slope as $20 \%$ of the actual slope. However, some parts of a stream that do not have high slopes might not be candidates for this CP. Irrigation land leveling, which was represented in the model by reducing slope and slope length, might not be useful in areas with an existing irrigation system where there is no need of irrigation land leveling. Moreover, the same irrigation land leveling methodologies might not be applied to different crop conditions. Irrigation pipeline, which was uniformly represented in the model by improving conveyance efficiency, may not be applicable to all of the systems in the HRU. In a large watershed modeling study, considerations relating to the irrigation appurtenances, pressure, frictions losses, and flow velocity might be impractical [48]. At present, a user has no ability to place the pipeline at a specific location in the HRU where they may be needed.

Irrigation water management controls the amount of irrigation water for the efficient utilization of available water. Controlling the application of irrigation water should not only be based on rainfall occurring on a specific day, it also should depend on the amount of antecedent rainfall. Although modeling nutrient reduction $\mathrm{CP}$ as a measure of restrictive $\mathrm{N}$ and $\mathrm{P}$ application scenarios reduced TP and TN losses, it also increased sediment losses, and caused a decrease in crop yield. We acknowledge that the simulation of nutrient management by uniformly reducing applied fertilizers may not provide useful information. Rather, this scenario should be based on information about soil nutrient status and crop nutrient requirements.

\section{Conclusions}

Many water quality programs have been launched to implement several CPs across the US. One of such programs, the MRBI, has been launched by the USDA-NRCS to control sediment and nutrients. The MRBI helps producers and invests through cost-share funding in designated MRBI watersheds to implement CPs. The MRBI is also interested in obtaining information relating to the quantification of the effectiveness of adopted CPs to reduce sediment and nutrient losses in each of the focus watersheds. The CP effectiveness information is necessary for future planning purposes. A modeling approach is found to be very useful in reporting such CP effectiveness information.

The impacts of seven MRBI-recommended CPs on water quality in the LRW were estimated with SWAT. The model setup procedure was improved to better reflect the landscape representation by incorporating wetlands in CAST land-use layers and cultivated crops in NLCD land-use layers. Moreover, no thresholds were used for land use, soil, and slope, to minimize the loss of spatial information, better represent hydrological processes, and accurately assess water quality results. The model was setup with the most recent available datasets at the time of study, and was calibrated and validated for total flow, surface flow, base flow, sediment, TP, and NO3-N at the Colt site, and for total flow, surface flow, and base flow at the Palestine site. 
The statistical results for the calibration and validation were found to be satisfactory or better, except for a few RSR values for the calibration period. The critical area planting CP was found to be the most effective practice for reducing the overall predicted nutrient and sediment loss at the HRU level, followed by filter strip, irrigation land leveling, grade stabilization structure, irrigation pipeline, nutrient management, and irrigation water management. The results reported in this study might provide an insight as to what can be expected when a specific management practice is implemented. The study also suggests that not all CPs can be very well modeled, and there is a need to come up with better representation algorithms for CPs.

In the future, additional work is needed to model CPs accurately in the watershed, requiring detailed knowledge of the range of practices already existing. Modeling different combinations of CPs and analyzing the cost-effectiveness of targeted practices are additional areas of future research. Moreover, advanced CP tools that allow users to interactively select and simulate specific CPs can be used in the future to support policy in a better way.

Acknowledgments: The authors would like to thank various state and federal agencies for providing the much-needed input data. Thanks also go to the staff members Arkansas High Performance Computing Center (AHPCC) at the University of Arkansas for helping with the resources needed to compile SWAT on supercomputer. The funding for this project was provided by the Arkansas Natural Resources Commission (ANRC-Project 11-1900 FY 11 CWA Section 319(h)) and Natural Resources Conservation Service (NRCS Agreement No. 68-7103-10-393).

Author Contributions: Gurdeep Singh, Dharmendra Saraswat, and Andrew Sharpley conceived and designed the modeling process and wrote the paper; Gurdeep Singh analyzed the data and executed the modeling process.

Conflicts of Interest: The authors declare no conflict of interest.

\section{References}

1. Costa, J.E. Effects of agriculture on erosion and sedimentation in the Piedmont Province, Maryland. Geol. Soc. Am. Bull. 1975, 86, 1281-1286. [CrossRef]

2. Alexander, R.B.; Smith, R.A.; Schwarz, G.E.; Boyer, E.W.; Nolan, J.V.; Brakebill, J.W. Differences in phosphorus and nitrogen delivery to the Gulf of Mexico from the Mississippi river basin. Environ. Sci. Technol. 2008, 42, 822-830. [CrossRef] [PubMed]

3. USDA Mississippi River Basin Healthy Watersheds Initiative. Available online: https: / /aaes.uark.edu/ discovery-farms/Documents/MBRI_Fact_Sheet.pdf (accessed on 25 March 2018).

4. National Management Measures to Control Nonpoint Source Pollution from Agriculture. Available online: https:/ / www.epa.gov/nps/national-management-measures-control-nonpoint-source-pollutionagriculture (accessed on 25 March 2018).

5. Liu, T.; Bruins, R.J.; Heberling, M.T. Factors Influencing Farmers' Adoption of Best Management Practices: A Review and Synthesis. Sustainability 2018, 10, 432. [CrossRef]

6. USDA Mississippi River Basin Healthy Watersheds Initiative. Available online: http://www.nrcs.usda.gov / Internet/FSE_DOCUMENTS/ / nrcs143_008142.pdf (accessed on 25 March 2018).

7. USDA Mississippi River Basin Healthy Watersheds Initiative. Available online: http:/ / www.nrcs.usda.gov / wps/portal/nrcs/detail/ia/programs/landscape/?cid=nrcs142p2_007958 (accessed on 25 March 2018).

8. USDA Mississippi River Basin Healthy Watersheds Initiative. Available online: http://www.nrcs.usda.gov/ wps/portal/nrcs/detailfull/national/home/?cid=stelprdb1048200 (accessed on 25 March 2018).

9. Seaber, P.R.; Kapinos, F.P.; Knapp, G.L. Hydrologic Units Maps, U.S. Geological Survey Water Supply Paper 2294. 1987. Available online: https:/ / pubs.usgs.gov/wsp/wsp2294/ (accessed on 25 March 2018).

10. Meals, D.W.; Dressing, S.A.; Davenport, T.E. Lag time in water quality response to best management practices: A review. J. Environ. Qual. 2010, 39, 85-96. [CrossRef] [PubMed]

11. Sharpley, A.; Jarvie, H.P.; Buda, A.; May, L.; Spears, B.; Kleinman, P. Phosphorus legacy: Overcoming the effects of past management practices to mitigate future water quality impairment. J. Environ. Qual. 2013, 42, 1308-1326. [CrossRef] [PubMed]

12. Arabi, M.; Govindaraju, R.S.; Hantush, M.M.; Engel, B.A. Role of watershed subdivision on modeling: The Effectiveness of Best Management Practices with SWAT. J. Am. Water Res. Assoc. 2006, 42, 513-528. [CrossRef] 
13. Leh, M.D.; Sharpley, A.N.; Singh, G.; Matlock, M.D. Assessing the impact of the MRBI program in a data limited Arkansas watershed using the SWAT model. Agric. Water Manag. 2018, 202, 202-219. [CrossRef]

14. Folle, S.; Dalzell, B.; Mulla, D. Evaluation of Best Management Practices (BMPs) in Impaired Watersheds Using the SWAT Model; Minnesota Department of Agriculture: St. Paul, MN, USA, 2007. Available online: http:/ / www.mda.state.mn.us/protecting/cleanwater/research/ /media/Files/protecting/cwf/ swatmodel.ashx (accessed on 25 March 2018).

15. Neitsch, S.L.; Arnold, J.G.; Kiniry, J.G.; Williams, J.R. Soil and Water Assessment Tool Theoretical Documentation Version 2009; Technical Report No. 406; Texas Water Resources Institute: College Station, TX, USA, 2011. Available online: http:/ / swat.tamu.edu/media/99192/swat2009-theory.pdf (accessed on 25 March 2018).

16. Her, Y.; Frankenberger, J.; Chaubey, I.; Srinivasan, R. Threshold effects in HRU definition of the Soil and Water Assessment Tool. Trans. ASABE 2015, 58, 367-378. [CrossRef]

17. Gitau, M. A Quantitative Assessment of BMP Effectiveness for Phosphorus Pollution Control: The Town Brook Watershed, New York. Ph.D. Thesis, Pennsylvania State University, State College, PA, USA, 2003.

18. CAST. Land Use Land Cover: Fall 2006 (Raster); Center for Advanced Spatial Technologies: Fayettevile, AR, USA, 2007. Available online: http:/ / www.geostor.arkansas.gov (accessed on 25 March 2018).

19. ANRC. State of Arkansas Nutrient Reduction Strategy. Arkansas State Water Plan. 2014. Available online: https://static.ark.org/eeuploads/anrc/AR_Nutrient_Reduction_Strategy_101014.pdf (accessed on 25 March 2018).

20. Kalin, L.; Hantush, M.M. Hydrologic modeling of an eastern Pennsylvania watershed with NEXRAD and rain gauge data. J. Hydrol. Eng. 2006, 11, 555-569. [CrossRef]

21. Moon, J.; Srinivasan, R.; Jacobs, J.H. Streamflow estimation using spatially distributed rainfall in the Trinity River basin, Texas. Trans. ASABE 2004, 47, 1445-1451. [CrossRef]

22. Singh, G. A Watershed Scale Evaluation of Selected Second Generation Biofeedstocks on Water Quality. Master's Thesis, University of Arkansas, Fayetteville, AR, USA, 2012.

23. Pai, N.; Saraswat, D.; Daniels, M. Identifying priority subwatersheds in the Illinois River Drainage Area in Arkansas watershed using a distributed modeling approach. Trans. ASABE 2011, 54, 2181-2196. [CrossRef]

24. Chiang, L.; Chaubey, I.; Gitau, M.W.; Arnold, J.G. Differentiating impacts of land use changes from pasture management in a CEAP watershed using the SWAT model. Trans. ASABE 2010, 53, 1569-1584. [CrossRef]

25. Gorham, B.; Tullis, J. Final Report: 2006 Arkansas Land Use and Land Cover (LULC); Arkansas Natural Resource Commission: Little Rock, AR, USA, 2007.

26. Homer, C.; Dewitz, J.; Fry, J.; Coan, M.; Hossain, N.; Larson, C.; Herold, N.; McKerrow, A.; VanDriel, J.N.; Wickham, J. Completion of the 2001 National Land Cover Database for the conterminous United States. Photogramm. Eng. Remote Sens. 2007, 73, 337-341. [CrossRef]

27. Pai, N.; Saraswat, D. SWAT2009_LUC: A tool to activate the land use change module in SWAT 2009. Trans. ASABE 2011, 54, 1649-1658. [CrossRef]

28. Martinez-Martinez, E.; Nejadhashemi, A.P.; Woznicki, S.A.; Love, B.J. Modeling the hydrological significance of wetland restoration scenarios. J. Environ. Manag. 2014, 133, 121-134. [CrossRef] [PubMed]

29. Vadas, P.A.; White, M.J. Validating soil phosphorus routines in the SWAT model. Trans. ASABE 2010, 53, 1469-1476. [CrossRef]

30. Espinoza, L.; Slaton, N.A.; Mozaffari, M. Understanding the Number on Your Soil Test Report; University of Arkansas Extension Publications: Little Rock, AR, USA, 2007. Available online: https:/ /www.uaex.edu/ publications/PDF/FSA-2118.pdf (accessed on 25 March 2018).

31. Mehlich, A. Mehlich 3 soil test extractant: A modification of Mehlich 2 extractant. Commun. Soil Sci. Plant Anal. 1984, 15, 1409-1416. [CrossRef]

32. Sharpley, A.N.; Jones, C.A.; Gray, C.; Cole, C.V. A simplified soil and plant phosphorus model: II. Prediction of labile, organic, and sorbed phosphorus. Soil Sci. Soc. Am. J. 1984, 48, 805-809. [CrossRef]

33. Santhi, C.; Arnold, J.G.; Williams, J.R.; Dugas, W.A.; Srinivasan, R.; Hauck, L.M. Validation of the SWAT model on a large river basin with point and nonpoint sources. J. Am. Water Res. Assoc. 2001, 37, 1169-1188. [CrossRef]

34. Engel, B.; Storm, D.; White, M.; Arnold, J.; Arabi, M. A hydrologic/water quality model application protocol. J. Am. Water Works Assoc. 2007, 43, 1223-1236. [CrossRef] 
35. White, M.J.; Harmel, R.D.; Arnold, J.G.; Williams, J.R. SWAT check: A screening tool to assist users in the identification of potential model application problems. J. Environ. Qual. 2014, 43, 208-214. [CrossRef] [PubMed]

36. Moriasi, D.; Arnold, J.; Van Liew, M.; Bingner, R.; Harmel, R.; Veith, T. Model evaluation guidelines for systematic quantification of accuracy in watershed simulations. Trans. ASABE 2007, 50, 885-900. [CrossRef]

37. Mukundan, R.; Radcliffe, D.E.; Risse, L.M. Spatial resolution of soil data and channel erosion effects on SWAT model predictions of flow and sediment. J. Soil Water Conserv. 2010, 65, 92-104. [CrossRef]

38. Yen, H.; Jeong, J.; Feng, Q.; Deb, D. Assessment of input uncertainty in SWAT using latent variables. Water Res. Manag. 2015, 29, 1137-1153. [CrossRef]

39. Runkel, R.L.; Crawford, C.G.; Cohn, T.A. Load Estimator (LOADEST): A FORTRAN Program for Estimating Constituent Loads in Streams and Rivers. US Department of the Interior, US Geological Survey; 2004. Available online: http:/ / pubs.usgs.gov/tm/2005/tm4A5/pdf/508final.pdf (accessed on 25 March 2018).

40. USDA-NRCS Conservation Practice Standard Filter Strip. Available online: https:/ /www.nrcs.usda.gov / Internet/FSE_DOCUMENTS/stelprdb1241319.pdf (accessed on 25 March 2018).

41. USDA-NRCS Conservation Practice Standard Critical Area Planting. Available online: https://www.nrcs. usda.gov/Internet/FSE_DOCUMENTS/stelprdb1241316.pdf (accessed on 25 March 2018).

42. Santhi, C.; Srinivasan, R.; Arnold, J.G.; Williams, J. A modeling approach to evaluate the impacts of water quality management plans implemented in a watershed in Texas. Environ. Model. Softw. 2006, 21, 1141-1157. [CrossRef]

43. USDA-NRCS Conservation Practice Standard Grade Stabilization Structure. Available online: https://www. nrcs.usda.gov/Internet/FSE_DOCUMENTS/stelprdb1263175.pdf (accessed on 25 March 2018).

44. USDA-NRCS Conservation Practice Standard Irrigation Land Leveling. Available online: https://www.nrcs. usda.gov/Internet/FSE_DOCUMENTS/stelprdb1101834.pdf (accessed on 25 March 2018).

45. Kannan, N.; Jeong, J.; Srinivasan, R. Hydrologic modeling of a canal-irrigated agricultural watershed with irrigation best management practices: Case study. J. Hydrol. Eng. 2011, 16, 746-757. [CrossRef]

46. USDA-NRCS Conservation Practice Standard Irrigation Pipeline. Available online: https:/ /www.nrcs.usda. gov /Internet/FSE_DOCUMENTS/stelprdb1046882.pdf (accessed on 25 March 2018).

47. USDA-NRCS Conservation Practice Standard Irrigation Water Management. Available online: https:// www.nrcs.usda.gov/Internet/FSE_DOCUMENTS/stelprdb1263179.pdf (accessed on 25 March 2018).

48. USDA-NRCS Conservation Practice Standard Nutrient Management. Available online: https://www.nrcs. usda.gov/Internet/FSE_DOCUMENTS/stelprdb1046896.pdf (accessed on 25 March 2018).

49. Moriasi, D.N.; Gowda, P.H.; Arnold, J.G.; Mulla, D.J.; Ale, S.; Steiner, J.L. Modeling the impact of nitrogen fertilizer application and tile drain configuration on nitrate leaching using SWAT. Agric. Water Manag. 2013, 130, 36-43. [CrossRef]

50. Hu, X.; McIsaac, G.F.; David, M.B.; Louwers, C.A.L. Modeling riverine nitrate export from an east-central Illinois watershed using SWAT. J. Environ. Qual. 2007, 36, 996-1005. [CrossRef] [PubMed]

51. Schilling, K.E.; Wolter, C.F. Modeling nitrate-nitrogen load reduction strategies for the Des Moines River, Iowa using SWAT. Environ. Manag. 2009, 44, 671-682. [CrossRef] [PubMed]

52. SWAT Theoretical Documentation. Available online: https://swat.tamu.edu/media/99192/swat2009theory.pdf (accessed on 25 March 2018).

53. White, M. (Grassland Soil and Water Research Laboratory USDA-ARS, Temple, Texas, USA). Personal communication, 2014.

54. Srinivasan, R.; Ramanarayanan, T.; Arnold, J.; Bednarz, S. Large area hydrologic modeling and assessment part II: model application. J. Am. Water Res. Assoc. 1998, 34, 91-101. [CrossRef]

55. Song, X.; Zhang, J.; Zhan, C.; Xuan, Y.; Ye, M.; Xu, C. Global sensitivity analysis in hydrological modeling: Review of concepts, methods, theoretical framework, and applications. J. HydroL. 2015, 523, 739-757. [CrossRef]

56. Uusitalo, L.; Lehikoinen, A.; Helle, I.; Myrberg, K. An overview of methods to evaluate uncertainty of deterministic models in decision support. Environ. Model. Softw. 2015, 63, 24-31. [CrossRef]

57. Van Griensven, A.; Meixner, T. Methods to quantify and identify the sources of uncertainty for river basin water quality models. Water Sci. Technol. 2006, 53, 51-59. [CrossRef] [PubMed] 
58. Chu, T.; Shirmohammadi, A.; Montas, H.; Sadeghi, A. Evaluation of the SWAT model sediment and nutrient components in the piedmont physiographic region of Maryland. Trans. ASABE 2004, 47, 1523-1538. [CrossRef]

59. White, M.J.; Arnold, J.G. Development of a simplistic vegetative filter strip model for sediment and nutrient retention at the field scale. Hydrol. Process. 2009, 23, 1602-1616. [CrossRef]

60. Parajuli, P.B.; Mankin, K.R.; Barnes, P.L. Applicability of targeting vegetative filter strips to abate fecal bacteria and sediment yield using SWAT. Agric. Water Manag. 2008, 95, 1189-1200. [CrossRef]

61. Tuppad, P.; Santhi, C.; Srinivasan, R.; Williams, J.R. Best Management Practice (BMP) Verification using Observed Water Quality Data and Watershed Planning for Implementation of BMPs. TSSWCB PROJECT 2009. Available online: https://www.tsswcb.state.tx.us/sites/default/files/files/programs/nonpoint-sourcemanagment/Completed\%20Projects/04-18-FR-RICHLNDBMP-09-21-10.pdf (accessed on 25 March 2018).

62. Arabi, M.; Frankenberger, J.R.; Engel, B.A.; Arnold, J.G. Representation of agricultural conservation practices with SWAT. Hydrol. Process. 2008, 22, 3042-3055. [CrossRef]

63. Kannan, N.; Omani, N.; Miranda, R. Water quality modeling of an agricultural watershed with Best Management Practices. Int. J. Res. Eng. Technol. 2014, 3, 553-564. [CrossRef]

64. Pagani, A.; Sawyer, J.; Mallarino, A. Site-Specific Nutrient Management: For Nutrient Management Planning to Improve Crop Production, Environmental Quality, and Economic Return; Extension and Outreach Publications: Horticulture Hall Ames, IA, USA, 2013. Available online: http:/ /lib.dr.iastate.edu/extension_pubs/116/ (accessed on 25 March 2018).

65. Bosch, N.S.; Allan, J.D.; Selegean, J.P.; Scavia, D. Scenario-testing of agricultural best management practices in Lake Erie watersheds. J. Great Lakes Res. 2013, 39, 429-436. [CrossRef]

66. Giri, S.; Nejadhashemi, A.P.; Woznicki, S.; Zhang, Z. Analysis of best management practice effectiveness and spatiotemporal variability based on different targeting strategies. Hydrol. Process. 2014, 28, 431-445. [CrossRef]

67. White, M.J.; Storm, D.E.; Busteed, P.R.; Stoodley, S.H.; Phillips, S.H. Evaluating nonpoint source critical source area contributions at the watershed scale. J. Environ. Qual. 2009, 38, 1654-1663. [CrossRef] [PubMed]

68. Gopalakrishnan, G.; Negri, M.; Snyder, S. A Novel Framework to Classify Marginal Land for Sustainable Biomass Feedstock Production. J. Environ. Qual. 2011, 40, 1593-1600. [CrossRef] [PubMed]

69. Singh, G.; Saraswat, D. Development and evaluation of targeted marginal land mapping approach in SWAT model for simulating water quality impacts of selected second generation biofeedstock. Environ. Model. Softw. 2016, 81, 26-39. [CrossRef] 